\title{
Recovery of Metallic Values in Smart Cards
}

ISSN: 2576-8840

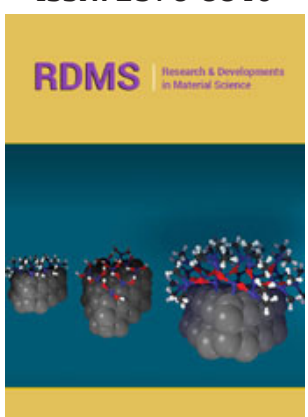

*Corresponding author: Fatma Arslan, Department of Mineral Processing Engineering, Istanbul Technical University, Istanbul, Turkey

Submission: 眥 October 29, 2021

Published: 眥 November 09, 2021

Volume 16 - Issue 1

How to cite this article: Candeniz Uysal, Selim Ertürk, Fatma Arslan, Cüneyt Arslan. Recovery of Metallic Values in Smart Cards. Res Dev Material Sci. 16(1). RDMS.000878. 2021.

DOI: 10.31031/RDMS.2021.16.000878

Copyright@ Fatma Arslan. This article is distributed under the terms of the Creative Commons Attribution 4.0 International License, which permits unrestricted use and redistribution provided that the original author and source are credited.

\section{Candeniz Uysal ${ }^{1}$, Selim Ertürk ${ }^{1}$, Fatma Arslan ${ }^{2 *}$ and Cüneyt Arslan ${ }^{1}$}

${ }^{1}$ Department of Metallurgical and Materials Engineering, Istanbul Technical University, Istanbul, Turkey

${ }^{2}$ Department of Mineral Processing Engineering, Istanbul Technical University, Istanbul, Turkey

\begin{abstract}
Today, smart cards which include a small microchip are very widely used in our daily lives. The chief among these is credit cards. In addition, gift shopping card, phone card, sim card, hotel room card involves great proportions. They generally include many precious metals in their body, including noble metals, and semi-noble metals; predominantly gold, silver, copper, etc. The aim of this experimental work is to recover the metals from the smart cards by hydrometallurgical processes namely acidic leaching $\mathrm{HNO}_{3}$ and Aqua Regia) followed by precipitation and cementation. Three different types of smart cards; credit cards supplied from different banks, telephone cards produced for Turk Telekom, and sim cards from three different mobile service providers, are used in the experimental work. As a result of this study, almost all copper, silver, and gold are recovered according to the experimental flowsheet proposed.
\end{abstract}

\section{Introduction}

Rapid global technological developments have led to the rising production of electronic waste that presents both challenges and opportunities in its recycling. High metal values in these types of wastes make them attractive for recovery. Treatment processes for metals recovery from them are generally given in three groups as pyrometallurgy (roasting, smelting), hydrometallurgy (leaching, separation), and biohydrometallurgy (leaching, adsorption). Recycling of precious metals from WEEE (Waste Electrical \& Electronic Equipment) typically combined with mechanical pretreatment (manually dismantling, separation and shredding) to segregate the valuable components followed by hydrometallurgical treatments through leaching [1-4]. Aqua regia and mineral acids such as hydrochloric acid ( $\mathrm{HCl})$, nitric acid $\left(\mathrm{HNO}_{3}\right)$, and sulfuric acid $\left(\mathrm{H}_{2} \mathrm{SO}_{4}\right)$ are used for the dissolution of PMs (Precious Metals) from WEEE components [2]. Acidic leachates produced are further treated for the recovery of PMs using conventional separation techniques, solvent extraction, membrane filtration, cementation, ion exchange, adsorption, and so forth $[3,5]$.

Smart cards are plastic cards which include a small microchip. This microchip has a memory between 1 and 256 kilobytes of ROM and an operating system that has been written on. The reason why these cards are named as smart cards is that they may contain and process various kinds of data [6]. A smart card, in accordance with the programming of the microprocessor's, can be used as bank card, credit card, driver's license, library membership card, code card for electronic shopping, football club membership cards, electronic wallet, etc., at the same time. Today, smart cards are very widely used in our daily lives. The chief among these is credit cards. In addition, gift shopping card, phone card, sim card, hotel room card involves great proportions. These microprocessors generally include many precious metals in their body, including noble metals, and semi-noble metals; predominantly gold, silver, copper, etc.

Metal ratio of a microprocessor has a big effect on its area of usage [7]. While the size of a smart card $(86 \times 54 \times 0.8 \mathrm{~mm})$ is regulated by the ISO-7810 standard, the smart card's physical characteristics, chip's location on the credit card, the card material, magnetic stripe, signature 
region, the hologram on the card, picture, relief, etc. are defined by the IS0-7816 standard [8,9]. Smart cards are divided into three groups depending on the memory; memory only, security logic memory, and memory with its own processor. Additionally, they can be investigated as two groups, according to their connection type; contact and contactless.

Today, smart cards have a big area of usage. According to the data of the Interbank Card Center (BKM), as of the end of June 2021, 79.8 million credit cards, 141.5 million debit cards and 50 million prepaid cards are used in Turkey [10]. In addition, according to the research of We Are Social, the number of mobile phone users in Turkey has reached 59 million. Of these, 77 percent, or 45 million, use smartphones. Thus, it can be said that the number of SIM cards in use is around 59 million [11]. Also, the amount of phone cards, meal cards, etc., such as Sodexho and Ticket is nearly the same as others. As of December 2017, there were 20.5 billion credit, debit, and prepaid cards in circulation worldwide including global generalpurpose cards [12]. With consumers worried about touching surfaces during the coronavirus pandemic, the use of mobile payments and contactless credit or debit cards has significantly increased in this term [13]. The aim of this experimental work is to recover the metals from the smart cards by using the similar processes which have used in the recycling of WEEE's.

\section{Material and Method}

Three different types of smart cards; credit cards supplied from different banks, telephone cards produced for Turk Telekom, and

sim cards from three different mobile service providers, are used in the experimental work. Every smart card is analyzed by wet and dry analysis methods to obtain their precious metal contents. Chemical analyses of the smart cards are shown in the Table 1.

Table 1: Chemical composition of smart cards.

\begin{tabular}{|c|c|c|c|}
\hline Metal & Credit Card & Sim Card & Telephone Card \\
\hline $\mathrm{Cu}$ & $11.16 \%$ & $14.90 \%$ & $4.87 \%$ \\
\hline $\mathrm{Au}$ & $0.12 \%$ & $0.14 \%$ & $0.04 \%$ \\
\hline $\mathrm{Ag}$ & $0.13 \%$ & $0.13 \%$ & $0.03 \%$ \\
\hline $\mathrm{Ni}$ & $1.57 \%$ & $1.74 \%$ & $0.54 \%$ \\
\hline
\end{tabular}

Chips are taken from the smart cards by a specially designed apparatus and weighted. After chips are dismantled from the smart cards, they were hold in hot water for 30 minutes to separate plastic part and chip. Weights of the raw smart card, taken part (chip and plastic body) and chip only are given in Table 2 and photographs of smart cards and chips are shown in Figure 1. Recycling of the plastic residue, from which the chip is removed is not a subject of this research.

Table 2: Weight of the various smart card parts.

\begin{tabular}{|c|c|c|c|}
\hline & Raw Card & Chip + Plastic & Chip Only \\
\hline Credit card & $5.25 \mathrm{~g}$ & $0.20 \mathrm{~g}$ & $0.10 \mathrm{~g}$ \\
\hline Phone card & $5.30 \mathrm{~g}$ & $0.24 \mathrm{~g}$ & $0.05 \mathrm{~g}$ \\
\hline Sim card & $0.38 \mathrm{~g}$ & $0.19 \mathrm{~g}$ & $0.09 \mathrm{~g}$ \\
\hline
\end{tabular}

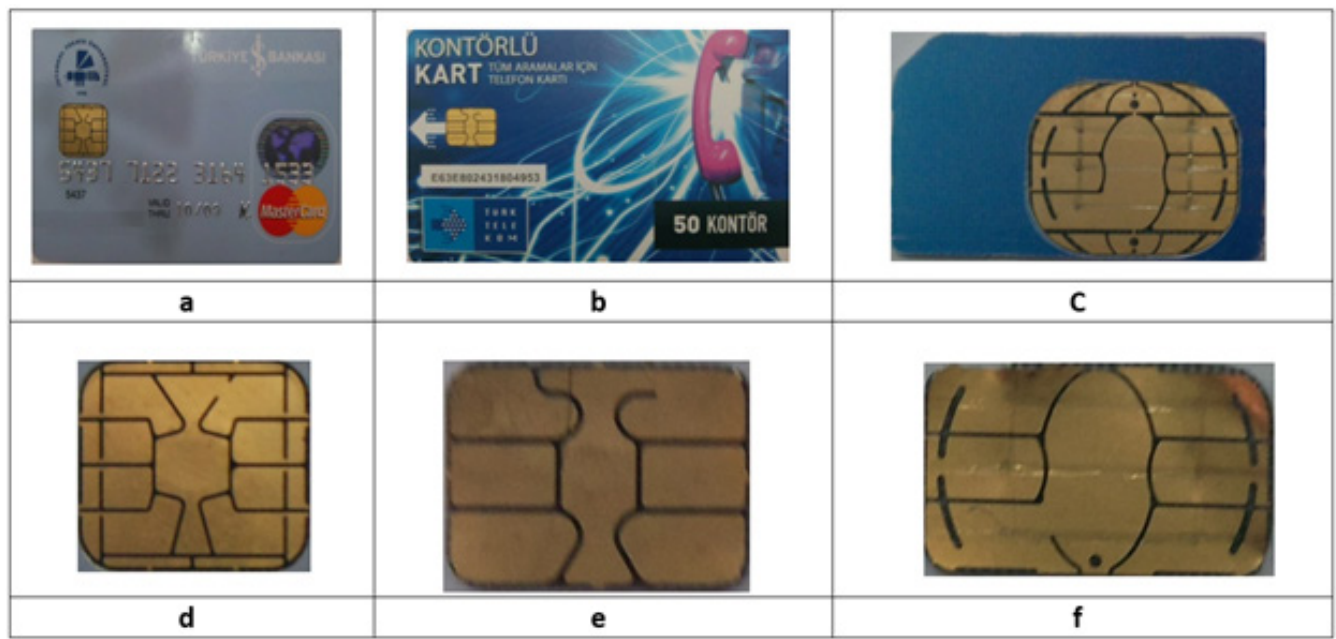

Figure 1: Photographs of the smart card and chips in different steps of the process (a) Credit card (b) Telephone card (c) Sim card (d) Credit card chip (e) Telephone card chip (f) Sim card chip.

Smart cards contain more than one metal $\mathrm{Au}, \mathrm{Ag}, \mathrm{Cu}, \mathrm{Ni}$, and Zn) which exist all together. Their similar physical and chemical properties make it hard to separate them individually. At first step; silver, copper, and nickel are taken by $\mathrm{HNO}_{3}$ leaching. After that, copper and silver are separated by cementation. Silver is precipitated by copper powder from that solution. Afterwards copper is separated by zinc powder. Residue from $\mathrm{HNO}_{3}$ leaching is treated with aqua regia. Aqua regia is the only aqueous mixture which dissolves gold. Gold is precipitated from the acidic solution selectively. The most known chemicals for gold precipitation from acidic solutions are ferrous sulphate, sodium nitrite, sulphur dioxide, and sulphides [14]. Sodium metabisulphide is chosen as the precipitation agent. The practice of gold precipitation by sodium metabisulphide was developed in 1916 at the Nipissing mill to replace aluminum precipitation $[15,16]$. Flow sheet that has been applied on the experiments is given in Figure 2. 


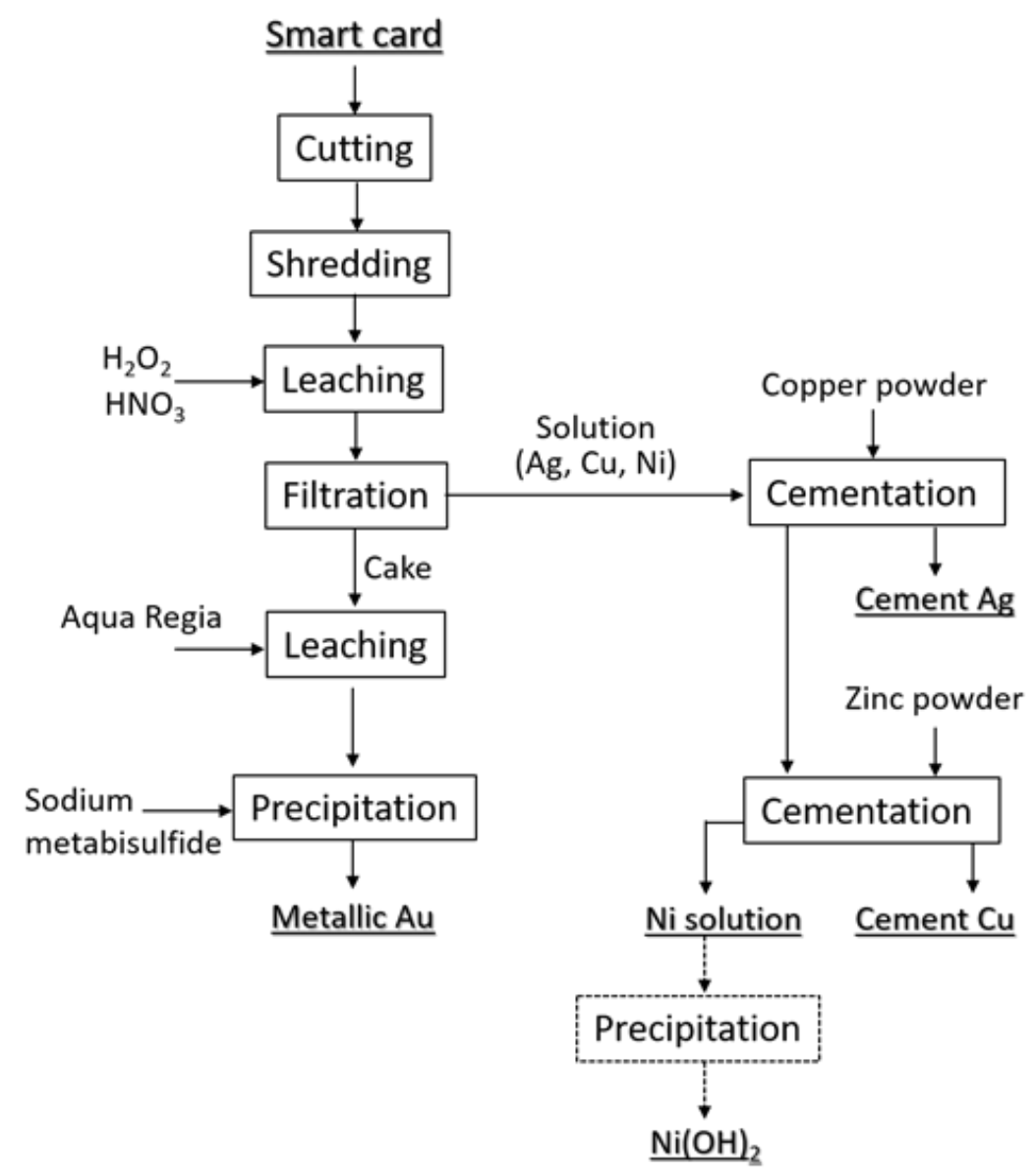

Figure 2: Flow sheet to recover metallic values in smart card chips.

\section{Results}

\section{Nitric acid leaching and cementation experiments}

In the nitric acid dissolution experiments five different solutions $(1-5 \%)$ are prepared and shredded chips are boiled for 30 minutes in that solutions separately. As a result, silver, copper, nickel, and zinc in the chip dissolve completely. After that, these metals are separated selectively by precipitation methods. Metallic ion concentrations after $\mathrm{HNO}_{3}$ leaching are given in Table 3.

Table 3: Metal concentrations after $5 \% \mathrm{HNO}_{3}$ leaching (in ppm).

\begin{tabular}{|c|c|c|c|}
\hline & Ag & Cu & Ni \\
\hline Credit Card & 6.845 & 456 & 50.4 \\
\hline Sim Card & 2.475 & 600 & 84.6 \\
\hline Telephone Card & 0.804 & 760 & 88.7 \\
\hline
\end{tabular}

Aqua regia leaching and gold precipitation experiments

Aqua regia (a mixture of acids containing 3 units of $\mathrm{HCl}$ and 1 unit of $\mathrm{HNO}_{3}$ ) is a highly oxidizing acid in which gold dissolves easily. $\mathrm{HNO}_{3}$ leach residue is leached in $5 \%$ aqua regia solution and all of the metallic parts in chip dissolve after 15 minutes of reaction time. Results are given in Table 4.
Table 4: Metal concentrations after 5\% aqua regia leaching (in ppm).

\begin{tabular}{|c|c|c|}
\hline & Au & Ag \\
\hline Credit Card & 3.561 & 0.166 \\
\hline Telephone Card & 7.393 & 0.109 \\
\hline Sim Card & 6.297 & 0.206 \\
\hline
\end{tabular}

One of the most known chemicals for gold precipitation is the sodium metabisulphide. Precipitation reaction with sodium metabisulphide is given below:

$$
2 \mathrm{AuCl}_{3}+3 \mathrm{Na}_{2} \mathrm{SO}_{3}+3 \mathrm{H}_{2} \mathrm{O} \rightarrow 2 \mathrm{Au}+6 \mathrm{HCl}+3 \mathrm{Na}_{2} \mathrm{SO}_{4}
$$

$1 \mathrm{M}$ sodium metabisulphide solution is added to the aqua regia solution after dissolution and stirred at 600-800rpm for 15 minutes. At the end It was found that gold is fully precipitated.

\section{Conclusion}

It can be seen from the experiments conducted in this work, silver and copper can be separated from nitric acid solutions by cementation successfully. Gold is precipitated by sodium metabisulphide from aqua regia solution with more than $90 \%$ for all the smart card types. Nickel in the solution can also be 
precipitated as nickel hydroxide. It can be concluded that, although a single smart card's metallic value may seem to be very low, it could present enormous economic value when we look at the amount of its global production.

\section{References}

1. Behnamfard A, Salarirad MM, Veglio F (2013) Process development for recovery of copper and precious metals from waste printed circuit boards with emphasize on palladium and gold leaching and precipitation. Waste Manag 33(11): 2354-2363.

2. Tuncuk A, Stazi V, Akcil A, Yazici EY, Deveci H (2012) Aqueous metal recovery techniques from e-scrap: hydrometallurgy in recycling. Miner Eng 25(1): 28-37.

3. Hasegawa H, Barua S, Wakabayashi T, Mashio A, Maki T, et al. (2018) Selective recovery of gold, palladium, or platinum from acidic waste. Microchemical Journal 139: 174-180.

4. Gouyon J, d'Orlyé F, Zimmerman J, Griveau S, Bedioui F, Varenne A (2020) Speciation and quantitation of precious metals in model acidic leach liquors, theoretical and practical aspects of recycling. Analytical and Bioanalytical Chemistry 412: 4595-4608.

5. Umeda H, Sasaki A, Takahashi K, Haga K, Takasaki Y, et al. (2011) Recovery and concentration of precious metals from strong acidic wastewater. Mater Trans 52: 1462-1470.
6. https://www.thalesgroup.com/en/markets/digital-identity-andsecurity/technology/smart-cards-basics

7. (2007) Gedik Investment Securities Inc., Plastic Kart Smart Card Operating Systems Tic. Inc. (Plaskart) Company Report.

8. https://www.iso.org/standard/70483.html

9. https://www.iso.org/standard/14732.html

10. https://www.diken.com.tr/turkiyede-kredi-karti-sayisi-798-milyonayukseldi-kartla-odemeler-yuzde-42-artti/

11. https://wearesocial.com/uk?s=how+many+cell+phones+are+in+use

12.https://nilsonreport.com/upload/issues/1140_0321.pdf

13. https://nrf.com/media-center/press-releases/coronavirus-leadsmore-use-contactless-credit-cards-and-mobile-payments

14. Demirkıran N, Ekmekyapar A, Künkül A, Baysar A (2007) A kinetic study of copper cementation with zinc in aqueous solutions. Int J Miner Process 82: 80-88.

15. https://www.911metallurgist.com/blog/melting-gold-precipitate

16. Demopoulos GP (2003) Nickel Hydroxide Precipitation from Aqueous Sulfate Media. JOM: The Journal of the Minerals, Metals \& Materials Society 55(8): 42-46. 